\section{Sleep Period Time}

Helga Peter

Marburg, Deutschland

\section{Synonyme}

SPT

\section{Definition}

Messtechnischer Begriff; Bezeichnung für die Gesamtdauer der Schlafperiode einschließlich der Wachphasen nach Schlafbeginn.

Siehe $\triangleright$ „Polysomnographie und Hypnogramm“. 